\title{
Correction to: Evolutionary divergence in tail regeneration between Xenopus laevis and Xenopus tropicalis
}

Shouhong Wang and Yun-Bo Shi ${ }^{*}$ (D)

\section{Correction to: Cell Biosci (2021) 11: 71} https://doi.org/10.1186/s13578-021-00582-9

The two Additional figures (Additional file 1) were accidentally left out in the linked file during the production of the published version of the paper by Wang and Shi [1].

\section{Supplementary Information}

The online version contains supplementary material available at https://doi. org/10.1186/s13578-021-00615-3.

Additional file 1: Fig. S1. A X. laevis tadpole amputated at stage 46 failed to regenerate the tail even after two months when the animal reached the metamorphic climax stage 63 and most of the tail was resorbed (a, scale bar is $6.9 \mathrm{~mm}$ ). The amputated tail tip remained as a stump (b, scale bar is $1.7 \mathrm{~mm}$; the red dashed line indicates the amputation plane). Fig. S2. Different tail regeneration phenotypes observed 7 days after amputation of stage 46 X. tropicalis tadpoles. (a) "Excellent": a regenerated tail with an elongation indistinguishable from normal tails, except for missing somite segmentation. (b) "Good", regenerated tail had defected elongation or lacked fin regeneration. (c) "Partial", regenerated tail was much shorter, or had defects in patterning and lacked fin regeneration, or had an elongated bulge formation. (d) "None", the tail had either a blunt end or a small bulge/stump at the amputated site. The regeneration score for the type of tail regeneration in $a, b, c, d$ was assigned $3,2,1,0$, respectively. The red dashed line indicates the amputation plane. Scale bar is $1.1 \mathrm{~mm}$.

Accepted: 21 May 2021

Published online: 04 June 2021

The original article can be found online at https://doi.org/10.1186/s13578021-00582-9.

*Correspondence: shi@helix.nih.gov

Section on Molecular Morphogenesis, Eunice Kennedy Shriver National Institute of Child Health and Human Development (NICHD), National

Institutes of Health $(\mathrm{NIH})$, Bethesda, MD, USA
Reference

1. Wang S, Shi Y-B. Evolutionary divergence in tail regeneration between Xenopus laevis and Xenopus tropicalis. Cell Biosci. 2021;11(1):71.

\section{Publisher's Note}

Springer Nature remains neutral with regard to jurisdictional claims in published maps and institutional affiliations.

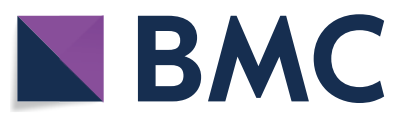

(C) The Author(s) 2021. This article is licensed under a Creative Commons Attribution 4.0 International License, which permits use, sharing, adaptation, distribution and reproduction in any medium or format, as long as you give appropriate credit to the original author(s) and the source, provide a link to the Creative Commons licence, and indicate if changes were made. The images or other third party material in this article are included in the article's Creative Commons licence, unless indicated otherwise in a credit line to the material. If material is not included in the article's Creative Commons licence and your intended use is not permitted by statutory regulation or exceeds the permitted use, you will need to obtain permission directly from the copyright holder. To view a copy of this licence, visit http://creativecommons.org/licenses/by/4.0/. The Creative Commons Public Domain Dedication waiver (http://creativecommons.org/publicdomain/zero/1.0/) applies to the data made available in this article, unless otherwise stated in a credit line to the data. 